\title{
Quality Assurance in Nigeria's Education System: Prospect and Challenges
}

\author{
Usman Yunusa Dangara ${ }^{\mathrm{a}, *} \&$ Madudili Geraldine Chinyere ${ }^{\mathrm{b}}$ \\ ${ }^{a}$ Department of Administration and Human Resources, FRSC (NVIS Plant) Awka, Anambra State, Nigeria \\ ${ }^{b}$ Department of Educational Management and Planning, Chukwuemeka Odumegwu Ojukwu University, Igbariam, Anambra State, Nigeria
}

\begin{abstract}
The study was conducted with the aim of establishing the relevance and challenges affecting quality assurance in Nigerian education system. Secondary data analysis methodology was adopted for the study. To easily achieve the objectives, the concept of quality assurance, strategies for building quality assurance into the education system and parameters for measuring quality assurance and challenges were discussed. The study identified some challenges affecting quality assurance to include shortage of funds, insecurity, policy inconsistency, and lack of regular training of staff etc. The paper concludes that since the essence of education is to make an individual useful quality assurance strategies should be monitored and evaluated on regular basis in order to improve the quality of the educational system in Nigeria. The study therefore recommends amongst others improved funding of the education sector, regular training and retraining of staff and provision of adequate security for learning environment in the country as a way forward.
\end{abstract}

Keywords: Quality; quality assurance, education, Nigeria.

\section{Introduction}

Nigeria has earned the designation of the giant of Africa by good worth of its size, population and vast resources. However, the pitiable state of infrastructure, low standard of education, wearing a way of value system, and many other tribulations prevalent in the society has caused the country to be fast losing its respect across the sphere. Nigeria is blessed amply with all the resources to be the best in all ramifications but yet the educational system is in shambles just because it is a product of Nigerian norm where in most cases normal things are abnormal and abnormal things are normal (Usman,2018).

The world has realized that the economic success of the states is directly determined by the quality of their education systems (Pavel,2012). It is worrying that while some countries have recognized the value of investing heavily in education as a vehicle for irremediable growth and brawny economy, Nigeria still prioritizes sustaining an excessively expensive system of governance ahead of instituting mechanisms that will guarantee quality education (Usman,2018).

The widespread recognition that education is a major driver of economic competitiveness in an increasingly knowledge-driven global economy has made high-quality education more important than ever before (Asiyai, 2015). Therefore, it is imperative for countries to strive towards raising candidates with higher level employment skills and sustain a globally competitive research and knowledge breeding base to the benefit of society (Ewuzie, 2020).

Quality education equips people with the ability that will enable them explore the world and manipulate it for their survival and establishment (Njoku, 2016).It has been the backbone of development in most countries of the world, because it propels both economic and social emancipation of a nation (Iniobong, 2013). Therefore, the means of

\footnotetext{
* Corresponding author.

E-mail address: usmanyud@gmail.com (Usman Yunusa Dangara)
} 
providing education should be effective to promote quality sustenance so as to enable the educational system to be well developed and effective (Okoli,2016).For quality education to be achieved in a nation, the principal actors of learning ( teachers, learners and the environment) should be cooperatively organized. In other words, the teacher must be adequate in quality and quantity, the students must be well trained and required facilities must be provided as well (Adegbesan, 2011).

The fact that Nigeria's education system is still characterized by a few high performing and many low performing schools is not acceptable to stakeholders in the education sector (Okebukola, 2013). The situation needs to be improved so that the country can compete with its peers in global competitive academic standards. In the education system, a vital mechanism required for the actualization of the educational objectives is to build a quality assurance model that will improve the quality of the teaching - learning process in the academic environment (Idialu, 2013).

Many nations around the globe now agree that the way out of series of bondage plaguing their nations and their citizens is through quality education (Njoku, 2016). Education in Nigeria has gone below its expectations. The system has derailed from its original intentions because of general neglect of the education sector (Ajayi \& Akindurite, 2007). The neglect has contributed to the present day collapse in the standard and quality of education in Nigeria (Uzorka, Uzorka \& Okobia, (2011).However, this situation in the education sector is reversible if there is a positive attitudinal change and conscious affirmative action by all stakeholders.

Stakeholders in the education sector are advocating that Nigeria education institutions at all levels should be encouraged and supported to develop strong internal quality assurance mechanism to drive the sector process and progress. They observe that countries that thrive in all sectors of their economy did embrace education as their bed rock (Ewuzie, 2020).

Achieving a robust quality education status in a nation does not happen by chance but achieved through implementation of well thought out strategies that can upgrade the education standard and improve quality of products churned out from the various citadels of learning. Amongst the strategies needed to guarantee the desired quality of education is to build quality assurance mechanism into the learning process (Thom-Otuya \& Inko-Tariah 2013).Quality and standards must be derived from a coherent policy framework, which provides clear directives and guidelines as well as principles, assumptions, structures, roles and responsibilities (Federal Ministry of Education (FME, 2014).

\section{Concept of Quality and Quality Assurance in Education}

Quality as a concept is multi-dimensional; hence it has been defined differently by stakeholders. Quality according to Okoro (2015) encapsulates the concept of meeting commonly agreed precepts or standards which may be defined by law, an institution, a coordinating body or a professional society. It is the degree with which a product, service, or phenomenon conforms to an established standard, and which makes it to be relatively superior to others (Oyewumi \& Fatoki, 2015).

According to UNESCO (2012),quality education is characterized by (i) Learners who are healthy, well-nourished and ready to participate and learn, and supported in by their families and communities (ii) Environments that are healthy, safe, protective and gender-sensitive, and provide adequate resources and facilities; (iii) Content that is reflected in relevant curricula and materials for the acquisition of basic skills, especially in the areas of literacy, numeracy and skills for life etc (iv) Processes through which trained teachers use child centered teaching approaches in classrooms, schools and skillful assessment to facilitate learning and reduce disparities; (v) Outcomes that encompass knowledge and attitudes linked to national goals for education and positive participation in society.

Quality of educational programme could be measured in terms of quality of input, quality of process, quality of context and quality of output (Adegbesan, 2011). Therefore, ensuring quality in education requires the right quantity and quality in everything that goes into the teaching-learning process or system as input and process (Okoye \& Ashibogwu, 2018).This kind of productive synergy can ensure a clear focus on school development, providing data on aspects such as school climate and the well-being of all members of the school community, effective teaching, learning and the impact of innovations (Adeniran \& Ekeruche, 2019). 
FME (2014) emphasizes that education quality assurance in Nigeria is a paradigm shift from the former practice of school supervision and inspection to a monitoring and evaluating process that provides a new operative mode of evaluation. This is carried out according to set standards that bring about improvement in teaching and learning. The strategic aim of quality assurance is therefore to prescribe standards and ensure that inputs, processes and outputs of the system meet these standards.

Quality assurance according to Harvey (1999) is a process of ensuring effective resource input control, refining the process and raising the standards of output in order to meet the set goals and satisfy public accountability. It is based on three main principles of control, accountability and improvement. Accountability usually requires meeting the preferences of stakeholders and control means that the institution does not merely control the expenditure of resources but also shows how high quality is achievable with the existing resources. Improvement enables the institution to get necessary input, refine the process and raise the standards of output in order to meet the goals set (Harvey, 1999)

In schools quality assurance activity focuses on whether learners are achieving as much as they can and whether everything the school provided has the best possible impact on learning (Olayanju, 2016). The system provides the evidence needed to establish confidence among all concerned that quality-related activities are being performed effectively (FME, 2014). In view of the fact that a systematic and consistent quality assurance system helps to establish an institution's good reputation and credibility, Adegbesan,(2011) averred that educational administrators are always faced with the responsibility of determining the priorities of management and other functions including adopting the management style that will ensure the seamless achievement of qualitative educational outcome.

The need for quality assurance in Nigerian schools cannot be overemphasized in order to ensure quality of teaching and learning. In this regard, Adegbesan (2011) enumerated the relevance of quality assurance to the education system in Nigeria to include; serving as indispensable component of quality control strategy in education; ensuring and maintaining high standard of education at all levels; assisting in monitoring and supervision of education; determining the quality of the teacher input; determining the number of classrooms needed based on the average class size to ensure quality control of education; determining the level of adequacy of the facilities available for quality control and regulating the prudent and judicious utilization of the available financial resources towards achieving the desired result.

\section{Building Quality into Nigeria's Education System}

To fulfill the purpose of quality assurance in Nigerian education system, scholars had listed some basic strategies and educational management functions that should be streamlined and practiced in similar terms by educational managers in order to enhance quality assurance in the education system.

Prominent amongst such strategies is good planning, regular monitoring and evaluation, quality control mechanism, effective supervision and conducive learning environment. Planning is an essential aspect of good management requires the ability of the manager to forecast and be able to formulate and select appropriate objectives and procedures to be followed within the school system with the aim of simply achieving the desired result (Okoro \& Oguguam, 2017).

Quality assurance is guaranteed when there is steady cycle of regular monitoring and evaluation activity with the aim of assessing the level of performance to find out how far set objectives are being met (Adegbesan, 2011). Quality control is one of the strategies for establishing quality assurance in the education system at all levels and should be of concern to the country in its drive towards economic recovery and technological development. (Olaleye \& Oyewole, 2016).

Supervision is an indispensable variable in ensuring effective teaching and learning which brings about improved process needed to build quality into education system (Zunaed,2011).It is a fundamental component of education administration that assists in effective management of the human and material resources in the industry (Agih, 2015). According to Mogbeyiteren, Azeez and Abina, (2019) learning can occur anywhere, but the positive learning outcome generally sought by educational systems happens in quality learning environment. Therefore, Availability of school facilities and the conduciveness of the school learning environment potent factors that influence improvement in the school system (Fehintola, 2014). 


\section{Quality assurance measuring parameters}

In the education system, appraisal is very important because it creates a platform for gap analysis between the anticipated and the attained outcome. In this regard, Nnorom and Gaius-Oke (2013) identified; quality of resource input, quality of output, quality of process and quality of content as the basic measuring criteria for quality assurance in Nigeria. Quality of resource input consists of the quality and quantity of both human and material resources put into educational production process (Nnorom\&Gaius-Oke, 2013).The quality of output implies the worth of the products of the education process which include academic achievement on tests, scores and progression and pass rates etc,(Giami \& Nwokamma,2019).

The output quality is a demonstration of the input quality thus; if the input is high-quality the output is assured to be equally of good quality and vice versa (Garba, 2014). Quality of process according Asiyai (2015) entails; studentteacher interaction, level of learner's participation and engagement in learning etc whereas the quality of content is another indicator which imply the value of curriculum content of learning in the education system. (Odo, 2015).

Onyesom and Ashibogwu, (2013) further emphasized that the quality assurance factors all play a joint role in a cyclic process as depicted below;

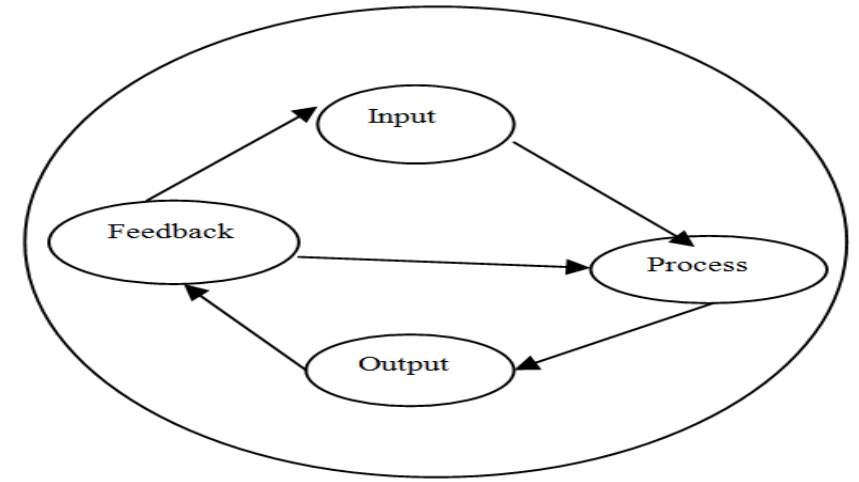

Fig. 1. Control mechanism for quality assurance in school (Onyesom \& Ashibogwu, 2013).

According to Onyesom and Ashibogwu (2013) as show in Fig.1 above, emphasis is on the input and process combination that produces the output. The feedback mechanism helps to re-evaluate the extent of achievement of the objectives and to determine where corrective actions are required. The input component includes the teachers, equipment, funds, infrastructures, supervisors. The process element includes the system, curriculum, teaching/learning interactions among others. The output elements are the school products, students' achievements, skills, attitudes and general behavior. The reactions from each of these elements are channeled back to the input segment through the feedback mechanism for proper control. Quality assurance should be a continuous process aimed at encouraging attitude change and teamwork and the inculcation of a value that acknowledges the student as the best judge of quality deserving the best possible service (Obadara \& Alaka, 2013).

\section{Challenges facing Quality Assurance in Nigeria}

The most prominent amongst the impediments of quality assurance in the education sector in Nigeria is underfunding. The issue of funding of education has been a recurrent decimal in the history of Nigeria's educational sector despite of the poor state of education system in the country (Amahua, 2010).An analysis by Abdusalam (2019) revealed that only $4 \%, 7.40 \%, 7.04 \%$ and $7.02 \%$ was allocated to the federal ministry of education by the government in 2016, 2017, 2018 and 2019 respectively. The obvious low allocation is definitely a hindrance to the sector in implementing policies that reassures quality education. 
In Nigeria, policies transforms recurrently with almost every change in countrys'leadership leading to inconsistencies in education policies (Igborgbor, 2012). These frequent change of policies signifies the absence a workable strategic plan for education sector development and constitute a serious challenge to the reforms in the education sector (Asiyai,2015).Another factor hindering quality assurance in Nigeria as observed by Odo (2015) is the politicization of appointments in the education sector. In some instances persons without requisite experience or academic background in education are appointed into leadership of education and related institutions (Odo, 2015). Such misfit appointments can lead to absence of total quality management work culture in education system (Garba, 2015).

Outbreak of diseases of public health concern like ebola and corona virus disease (COVID-19) is also hindrance to quality assurance. There is no arguing the fact that education is one of the major casualties of COVID-19 pandemic (Onunaiju, 2021). The pandemic has affected educational systems worldwide, leading to the near-total closures of schools thereby disrupting academic activities (UNESCO, 2020). More worrisome is that, in Nigeria the presidential task force (PTF) formed since the outbreak of COVID-19 is perceived to have done more to orchestrate fear than articulate a better understanding of the nature of the disease (Onunaiju,2021). School closures in response to the pandemics like COVID-19 etc have shaded more light on numerous issues affecting access and quality of education in Nigeria.

According to Chidobi and Eze-Thecla (2016) supervision has been a great challenge in education as it lacks the needed commitment and coordination to survive. The internal and external organs of quality assurance in education in this regard have failed and any system or project that is not properly supervised is bound to derail from its expectations and intended objectives (Amoor, 2010). In another dimension, persistent insecurity and conflicts remains a menace that resulted from the weak institutions and social organization in the country

(Abdullah, 2019). Over the years, educational institutions have become targets of bandits in carrying out their nefarious activities ranging from kidnappings and killings etc (Usman, 2020). Prominent amongst the cases which has disrupted school activities were recorded in Chibok in Borno state 2014, Dapchi in Yobe state 2018, Kankara in Katsina state 2020, Kagara in Niger state, 2021 and Afaka in Kaduna state, 2021 etc.

Okebukola (2013) observed that poor management and governance of institutions by administrators is also having a consequential effect on quality assurance in the education sector. This problem characterizes every other sectors of Nigerian society. In this regard, Anioke (2013) posits that the problem in Nigeria is that the institutions for managing education whether at the local or national level are weak and inefficient because of the democracy deficit in our polity. It is certain that as long as management continues to play nonchalant role, quality assurance will continue to be jeopardized in the nation's institutions (Uzorka et'al, 2011). Learning environment in modern day Nigeria has not been friendly with both learners and teachers. This has created a lot of quality vacuum in the learning process (Folami, Riaz \& Musolihu, 2021)

\section{Recommendation}

Quality assurance is the immediate and long-term solution to the problem of poor quality in education in Nigeria. The adoption and implementation of internal and external quality assurance mechanisms will facilitate the actualization of the goals of education in Nigeria. On the basis of this, the following measures are recommended to enhance the actualization of quality assurance in Nigerian education system.

a) The funding of the education sector should to be increased to enable the sector to conveniently implement its projects in line with globally acceptable best practices.

b) A framework that will encourage policy continuity should be instituted to ensure that succeeding governments adopts and completes on going education policy and/or modify them to meet societal needs rather than discarding them completely.

c) Nepotism in the system should be discouraged especially in terms of appointments. Appointments should be on merit to facilitate competence and productivity in the system. 
d) Regular capacity building training for staff through seminars, conferences and workshops should be conducted to broaden their knowledge with new skills and improved innovations that guarantees improved quality service delivery in the education system.

e) Adequate security should be provided in schools. Community participation in the administration of schools should be encouraged to promote a harmonious school-community relationship that will enhance the security of the learning environment.

f) Regular supervision and appraisal of educational programmes should be conducted to confirm compliance to quality assurance procedures. This will assist in identifying areas that needs remedial actions in implementation process.

\section{Conclusion}

The study was conducted with the aim of establishing the relevance and challenges affecting quality assurance in Nigerian education system. Secondary data analysis methodology was adopted for the study. The concept of quality assurance, strategies for building quality assurance into the education system and parameters for measuring quality assurance and challenges were discussed. The study identified some challenges affecting quality assurance to include shortage of funds, insecurity, policy inconsistency and lack of regular training of staff etc. The study therefore recommends amongst others improved funding of the education sector, regular training and retraining of staff and provision of adequate security for learning environment in the country as a way forward.

\section{References}

Abdullahi, A. (2019). Rural banditry, regional security, and integration in West Africa. Journal of Social and Political Sciences.2 (3), 644-654

Abdusalam, A., (2019). Education ministry gets 7.02\% of Nigeria's 2019 budget. Retrieved from http://educeb.com/ Education Ministry gets 7.02\% of Nigeria's 2019 budget

Adegbesan, S. O., (2011). Establishing quality assurance in Nigerian educational system: Implication for educational managers. Education Research and Reviews, 6(2), 147 - 151

Adeniran, A., \& Ekeruche M.A., (2019).How to implement quality education in Nigeria. http://southernvoice.org/how-to-implement-quality-education-in-nigeria

Agih, A. A., (2015). Effective school management and supervision: Imperative for quality education service delivery. International Multidisciplinary Journal, Ethiopia; 9(3), 62-74.

Ajayi, I. A. \& Akindurite, I. O. (2007). The unresolved issues of quality assurance in Nigeria universities. Journal of Sociology and Education in Africa.6 (1), 17 - 22

Amahua, A.S., (2010). Under-funding of education in Nigeria: The case of research and development for quality assurance in business education. Bus. Educ. Book Reading, 1(10): 184-200.

Amoor, S.S., (2010). The need to improve teacher quality in business education programme in Nigerian universities. Int. J. Edu. Res., 11(1): 42-51.

Anioke, B.O., (2013). Towards the changing role of the contemporary office: challenges of quality assurance in skills development in colleges of education. Nigerian Journal of Business Education.1 (2), 57-67.

Asiyai, R.I. (2015). Improving quality higher education in Nigeria: The roles of stakeholders. International Journal of Higher Education, 4(1), 61-70

Chidobi, R. U., \& Eze-Thecla, A. Y., (2016). Utilization of the quality assurance handbook in secondary school supervision of instruction in Enugu state, Nigeria. World Journal of Education. 6(4); 30-37 
Ewuzie, K., (2020) Quality assurance mechanism top educationists demand for 2020.https://businessday.ng/education/article/quality-assurance-mechanism-top-educationists-demand-for2020

Federal Ministry of Education (FME, 2014). The National Education Quality Assurance Policy. Lagos: NERDC press.

Fehintola,J.O.,(2014) Teachers' characteristics as correlates of students' academic performance among secondary school students in saki-west local government area of Oyo State. Journal of Educational and Social Research, 4(6), 459-468.

Folami, A.B., Riaz, A.S., \& Musolihu, M.O., (2021). Critical environmental factors affecting learning in college of education. Eduline: Journal of Education and Learning Innovation. 1 (1).http///doi.org/1035877/454RI.eduline400I

Garba, M.A. (2014). Quality assurance in education management: A key to sustainable teacher preparation in Nigeria. African Journal of Historical Science in Education, 10(1), 39-47.

Giami, C.B.N., \& Nwokamma, 1.O., (2019).Managing quality assurance for the transformation of university education in contemporary Nigeria. International Journal of Innovative Social Sciences \& Humanities Research, 7(2):83-92.

Harvey, L., (1999). An assessment of past and current approaches to quality in higher education. Australian Journal of Education. 43(3), 1-19

Idialu, E.E.,(2013);Ensuring Quality Assurance In Vocational Education. Contemporary Issues In Education Research.6 (4), 431-438

Igborgbor, G.C., (2012). Quality assurance for educational development in Africa. A Keynote Address Presented at the International Conference of the Institute of Education, Delta State University, Abraka, Nigeria, and June $12-15$

Iniobong, E.N., (2013). Challenges of globalization and quality assurance in Nigerian university education. International Education Studies; 6(1), 207-215.

Mogbeyiteren, O.L.B., Azeez, T.A., \& Abina, A.P., (2019).Impacts of quality assurance in managing education in Nigerian schools. International Journal of Innovative Education Research. 7(4), 131-138.

Njoku, L.N., (2016). Nigeria educational development and need for quality sustenance, thesis for B.A.Degree in international studies in education. School of education, University of Iceland

Nnorom, O.E. \& Gaius-Oke, H. (2013).Quality assurance in office technology and management in polytechnics in Nigeria. Association of Business Educators of Nigeria. 3(1), 45-49.

Obadara, O. E. \& Alaka, A. A. (2013). Accreditation and quality assurance in Nigerian universities. Journal of Education and Practice.4 (3), 34-41.

Odo, S.N., (2015).Achieving quality assurance in business education in Nigerian colleges of education; Journal of Teaching and Education, 4(3), 415-422.

Okebukola, P. (2013). Saving Nigeria from itself: towards redemption plan for education. A 50th anniversary lecture of faculty of education, university of Ibadan, Ibadan.

Okoli, N.J. (2016).University education system problems in Nigeria: Issues and Prospects. In M. Omolewa (Ed.). Discourse on the state of education in Nigeria (217-225). Ibadan: Laurel Educational Publishers Ltd.

Okoro, J.,(2015). Strategies for enhancing quality assurance in business teacher education programme in Nigerian universities: Journal of Education and Practice.6 (12), 202-209 
Okoro, C.O., \& Oguguam, C.N., (2017). Strategies for transformation of higher education towards enhanced productivity in Nigeria. The role of quality assurance. European Scientific Journal, 13(10), 137-148.

Okoye, K.R.E., \& Ashibogwu, N.K.,(2018).Strategies considered effective by business educators for quality assurance in business education programme in universities in South-South Nigeria; European Journal of Business and Management.10(2),43-48

Olaleye, F.O., \& Oyewole, B.K., (2016). Quality assurance in Nigerian university education: The role of the National university commission (NUC) as a regulatory body. International Journal of Academic Research in Business and Social Science, 6(12), 160-169,

Olayanju, O.J. (2016). Quality assurance innovative strategies for actualizing teachers' professionalism in Nigerian colleges of education. In M. Omolewa (ed.). Discourse on the State of education in Nigeria (585-602). Ibadan: Laurel Educational Publishers Ltd.

Onunaiju, (2021, January $18^{\text {th }}$ ).Questions about the integrity of PTF.Vanguard,pp.17.

Onyesom, M., \& Ashibogwu, N.K., (2013) Towards Quality Assurance in Business Education in Nigeria: Constraints and control. Asian Journal of Business Management. 5 (3), 306-312.

Oyewumi, C. F., \& Fatoki O. R., (2015).Quality assurance in teachers' education in Kwara State: Challenges and the way forward. Merit Research Journal of Education and Review .3(2), 119-125

Pavel, A.P., (2012). The importance of quality in higher education in an increasingly knowledge-driven society. International Journal of Academic Research in Accounting, Finance and Management Sciences.2 (1), 120127.

Thom-Otuya, B. E. N., \& Inko-Tariah, D. C. (2016). Quality education for national development: The Nigerian experience. African Educational Research Journal, 4(3), 101-108

UNESCO (2020). Education: From disruption to recovery. https://plus.google.com/+UNESCO (2020-03-04)

UNESCO (2012). Education webmaster: World conference on higher education framework and action. www.jyu/fi/unesco2003/conference.htm

Usman, M., (2020).Youth banditry in northern Nigeria: An eagle eye on the security and socio-economic impacts. Lapai International Journal of Politics.6 (1), 10-20

Usman,Y.D.,(2018,December 14).The imperativeness of re-assessing the quality of Nigerian education system: The Chronicle of education (Blog).http//thechronicleof education.net/2018/12/14/ the -imperativeness- of -reassessing -the- quality- of- Nigerian- education-system.

Uzorka,M.,Uzorka,C.,\& Okobia, A., (2011). Falling standards in education and its implication for national development. Rivers Journal of the Social Sciences, 1(2), 78-89.

Zunaed, C., (2011). Quality assurance of business education in Bangladesh. http://zunaed.blogspot.com/ 